Western North American Naturalist 68(1), (C) 2008, pp. 1-7

\title{
MONITORING IDAHO FESCUE GRASSLANDS IN THE BIG HORN MOUNTAINS, WYOMING, WITH A MODIFIED ROBEL POLE
}

\author{
Daniel W. Uresk ${ }^{1,2}$ and Thomas M. Juntti ${ }^{1}$
}

\begin{abstract}
The reliability of monitoring visual obstruction and estimating standing herbage with a modified Robel pole was examined for high-elevation meadows in sedimentary soils on the Bighorn National Forest, Wyoming. Our objectives were to (1) test a modified pole graduated with $1.27-\mathrm{cm}(0.5$-inch) bands for estimating standing herbage based on linear regression of visual obstruction readings (VORs) on standing herbage, (2) validate the derived regression, (3) provide sample size estimates, and (4) develop guidelines for monitoring mountain grasslands. Each transect had 20 visual obstruction stations spaced 10 meters apart with 4 visual obstruction readings at each station. At 4 stations, vegetation within a $0.25-\mathrm{m}^{2}$ area was clipped at ground level. VORs and clipped standing herbage were averaged by transect for analysis. Visual obstruction reliably predicted average standing herbage (dry weights) for mountain meadows $\left(r^{2}=0.81, s_{\bar{x}}=382 \mathrm{~kg} \cdot \mathrm{ha}^{-1}\right)$. Standing herbage ranged from $387 \mathrm{~kg} \cdot \mathrm{ha}^{-1}$ to $3930 \mathrm{~kg} \cdot \mathrm{ha}^{-1}$, with a mean of $1742 \mathrm{~kg} \cdot$ $\mathrm{ha}^{-1}$. A validation data set of 13 transects sampled across the range of variation in standing crop showed that $85 \%$ of transects fell within the $90 \%$ prediction limits. We recommend a minimum of 4 transects for monitoring key areas or small areas up to 259 ha (640 acres) when managers need to consider differences in VOR bands and address multiple objectives. Cluster analyses (ISODATA) applied to the pole readings resulted in 4 visual obstruction categories: short, short-intermediate, tall-intermediate, and tall. This tool provides a simple, reliable, and cost-effective (time-saving) alternative to clipping vegetation and obtaining dry weights for monitoring.
\end{abstract}

Key words: standing herbage, livestock, grazing, Robel pole, visual obstruction readings, cluster analysis.

Mention of a proprietary product does not constitute a guarantee or warranty of the product by USDA or the authors and does not imply its approval to the exclusion of other products that also may be suitable.

Monitoring standing herbage is a common method for managing livestock grazing, wildlife habitat, and plant diversity. However, direct herbage measurements are time consuming and expensive, and summarizing results is a slow process that can delay resource decisions. Using the Robel pole to estimate standing herbage indirectly using visual obstruction readings (VORs) has received considerable attention in the literature (Robel et al. 1970, Volesky et al. 1999, Benkobi et al. 2000, Vermeire and Gillen 2001). The pole is a simple, quick, and reliable tool for estimating standing herbage. The pole as originally developed by Robel (1970) was graduated in decimeters. Benkobi et al. (2000) modified the pole using $2.54-\mathrm{cm}$ (1-inch) VOR bands. However, for monitoring heavily grazed areas or short vegetation such as that occurring at high altitude or xeric sites, decimeter or 1-inch VOR bands are insufficiently precise; therefore, we employed a pole with 1.27 -cm (0.5-inch) VOR bands. The objectives of this study were to (1) test a modi- fied pole, graduated with 1.27 -cm (0.5-inch) VOR bands, for estimating herbage based on linear regression of VOR on standing herbage, (2) validate the relationship between standing herbage and VOR made with the modified Robel pole, (3) develop sample size estimates for the number of transects required to achieve adequate precision for monitoring, and (4) develop guidelines that provide a smooth transition between utilization-based and standing crop-based monitoring of mountain grasslands.

\section{Methods}

\section{Study Area}

This study was conducted on the Bighorn National Forest within the Big Horn Mountains of north central Wyoming. The Bighorn National Forest is approximately 448,258 ha (Girard et al. 1997). Grassy meadows were sampled at elevations ranging from $2316 \mathrm{~m}$ to $3048 \mathrm{~m}$. Annual precipitation averages $53 \mathrm{~cm}$ at Burgess Junction (2463 m elevation) and

${ }^{1}$ USDA Forest Service, Rocky Mountain Research Station, Rapid City, SD 57702.

2E-mail: ureska@rap.midco.net 


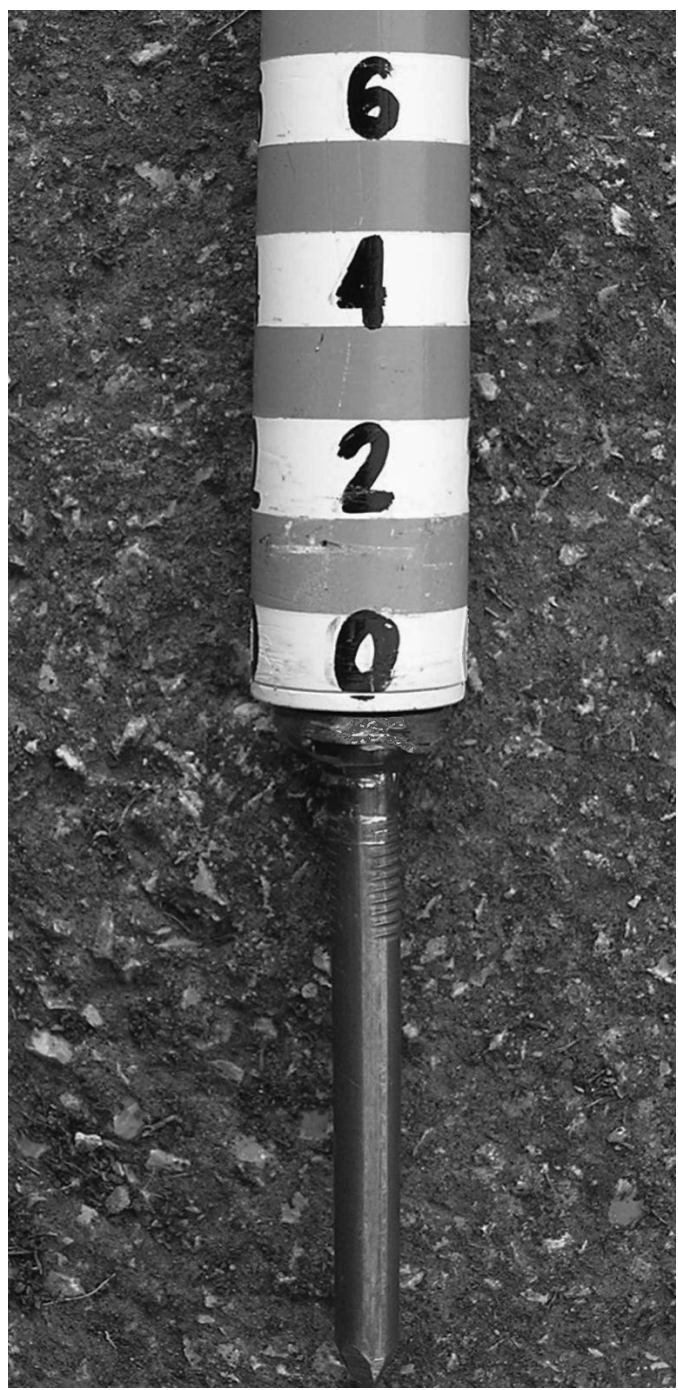

Fig. 1. VOR bands are 0.5 inches high and alternate white and gray, with the 1 st VOR band labeled as 0 . The 3-inch spike is attached.

ranges from 30 to $78 \mathrm{~cm}$. Temperature at Burgess Junction ranges from $-44^{\circ}$ to $31^{\circ} \mathrm{C}$, with an average of $0.8^{\circ} \mathrm{C}$ (WRCC 2005). Growing season at these elevations is between 50 and 55 days (Nesser 1986). The study area was confined to areas where soils are derived from sedimentary material. These soils generally support a greater and more diversified herbaceous cover than granitic soils (Hurd and Pond 1958). Also, sedimentary soils are more basic and generally fine textured with high nutrient levels and soil water holding capacity (Nesser
1986, USDA NRCS 1990) compared to granitic soils.

Vegetation in the open meadows is dominated by the Idaho fescue type (Beetle 1956, Girard et al. 1997). Idaho fescue (Festuca idahoensis) is the dominant grass. King fescue (Leukopoa kingii), mountain brome (Bromus marginatus), and lupine (Lupinus spp.) are major components. Many other forbs contribute significantly to the overall herbage production. Hurd (1961) and Beetle (1956) present plant species composition, vegetative production data, and soil descriptions of these rangelands.

\section{Data Collection and Analyses}

VOR and clipped standing herbage were sampled from mid-July to early September 2003. We modified the Robel pole as described by Robel et al. (1970) and Benkobi et al. (2000) by using 1.27-cm (0.5-inch) alternating white and grey VOR bands on the pole (Fig. 1). The VOR bands were numbered beginning with 0 at the bottom. A spike $7.6 \mathrm{~cm}$ in length was attached to the bottom of the pole and, during use, was pushed into the ground to the bottom ring (Fig. 1). VORs were made from a distance of $4 \mathrm{~m}$, with the reader's eyes at a height of 1 $\mathrm{m}$. The lowest visible band was recorded as the VOR. For example, if the lst VOR band, numbered as 0, was visible, the VOR was recorded as 0 . At each station, 4 VORs were recorded at $90^{\circ}$ intervals. The 4 VORs were then averaged for each station.

We used a stratified sampling design for data collection (Benkobi et al. 2000). Strata based on visual inspection were structured so that transects representing a range of vegetation heights from short to intermediate to tall were sampled. Transects were located randomly within the 3 strata (0-5 VOR bands, 6-10 VOR bands, 11-15+ VOR bands). Data were collected from a total of 131 transects. A GPS location was recorded at the beginning of each transect. VOR, standing herbage, and GPS reference points were incorporated into a geographical information system (GIS) data layer.

Along each 200-m transect, we recorded 4 VORs (1 for each cardinal direction) at each of 20 pole stations spaced $10 \mathrm{~m}$ apart. At 4 stations $(50,100,150$, and $200 \mathrm{~m}$ along the transect) standing herbage was clipped within a $0.25-\mathrm{m}^{2}$ circular hoop centered on the Robel pole. All vegetation was clipped to ground level, oven-dried at $60^{\circ} \mathrm{C}$ for 48 hours, and weighed 


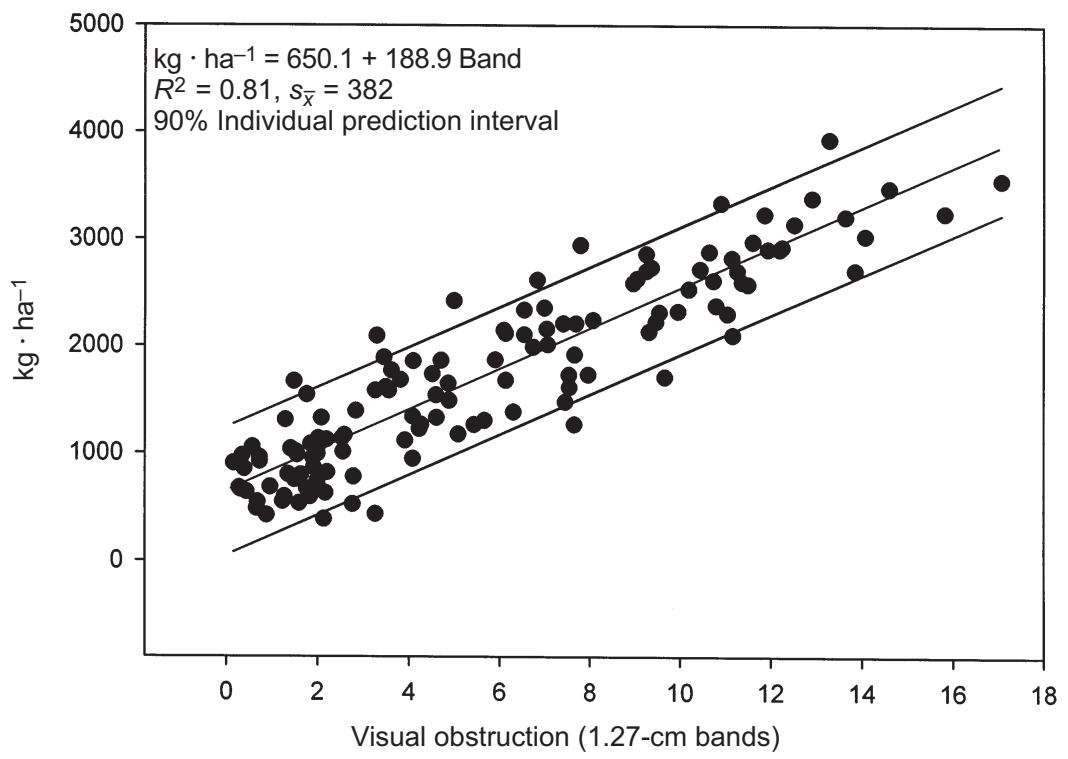

Fig. 2. Regression relationship between pole VOR bands and $\mathrm{kg} \cdot \mathrm{ha}^{-1}$ with $90 \%$ prediction bands for individual transects.

TABLE 1. Validation of the model (Fig. 2) during the 2nd year of sampling for 13 sites included visual obstruction readings (band height $=0.5$ inch $[1.27 \mathrm{~cm}])$ and measured herbage $\left(\mathrm{kg} \cdot \mathrm{ha}^{-1}\right)$ on sedimentary soils for $90 \%$ prediction limits from the model. A total of $85 \%$ of the sites were within the limits of the model.

\begin{tabular}{ccrcrc}
\hline Site & Band & $\mathrm{kg} \cdot \mathrm{ha}^{-1}$ & $\mathrm{UL}^{\mathrm{a}}$ & $\mathrm{LL}^{\mathrm{a}}$ & Outside \\
\hline 1 & 8.75 & 3571 & 3100 & 1501 & $*$ \\
2 & 8.49 & 2646 & 3051 & 1452 & \\
3 & 7.51 & 3131 & 2867 & 1268 & $*$ \\
4 & 6.54 & 2189 & 2682 & 1083 & \\
5 & 6.00 & 1830 & 2588 & 989 & \\
6 & 5.89 & 2481 & 2560 & 961 & \\
7 & 5.40 & 1987 & 2468 & 869 & \\
8 & 4.48 & 2259 & 2293 & 695 & \\
9 & 3.70 & 1737 & 2147 & 548 & \\
10 & 2.60 & 1938 & 1940 & 341 & \\
11 & 2.38 & 1377 & 1897 & 298 & \\
12 & 1.80 & 1291 & 1788 & 189 & \\
13 & 1.60 & 789 & 1751 & 153 & \\
\hline aUL $=$ upper prediction limits, LL $=$ lower prediction limits. &
\end{tabular}

to the nearest $0.1 \mathrm{~g}$. Standing herbage was expressed as $\mathrm{kg} \cdot \mathrm{ha}^{-1}$. To validate the model, an additional 13 transects were randomly selected in the following year throughout the range of data covered by the model.

All VORs and clipped herbage were averaged by transect for data analyses. We used linear regression (SPSS 2003) to analyze the relationship between VOR and herbage, and we used cluster analysis (ISODATA) to create management resource groupings (Ball and Hall 1967, del Morel 1975). Probability plots were examined for normality of residuals. For statistical analyses, $\alpha=0.05$, unless actual $P$ values are presented.

We developed sample size estimates for number of stations per transect and number of transects required to discriminate between the resource groupings (Benkobi et al. 2000) using power analysis to achieve estimates within $20 \%$ of the mean with an $80 \%$ confidence level (Graybill 1976, Steel and Torrie 1980). The number of transects required to detect differences in estimated standing herbage between spaced VOR bands at $\alpha=0.20$ were estimated based on nonoverlapping prediction intervals given the variance of the regression model (Neter et al. 1989, Hettmansperger and McKean 1998). The variance of the regression model includes the heterogeneity of the entire area sampled.

\section{Results}

The data showed a strong linear relationship between standing herbage and visual obstruction readings $\left(r^{2}=0.81, P=0.001, s_{\bar{x}}=\right.$ $382 \mathrm{~kg} \cdot \mathrm{ha}^{-1}$; Fig. 2). Probability plots showed a normal distribution of residuals. The slope $\left(188.9 \mathrm{~kg} \cdot \mathrm{ha}^{-1}\right.$ band $\left.^{-1}\right)$ and intercept $(650.1 \mathrm{~kg}$ - $\mathrm{ha}^{-1}$ ) of the regression model were both 
TABLE 2. Visual obstruction reading categories for short, short-intermediate, tall-intermediate and tall by VOR band number (band height $=0.5$ inch $[1.27 \mathrm{~cm}]$ ) on a modified Robel pole with corresponding kilograms of vegetation per hectare. VOR band number represents the visual obstruction reading (VOR). Categories are defined by cluster analysis for VOR bands.

\begin{tabular}{lccc}
\hline Category & Minimum & Mean & Maximum \\
\hline $\begin{array}{l}\text { Short }(n=47)^{\mathrm{a}} \\
\quad \text { VOR band }\end{array}$ & 0.2 & 2.0 & 3.0 \\
$\mathrm{~kg} \cdot \mathrm{ha}^{-1} \mathrm{~b}$ & 688 & 1028 & 1217 \\
$\begin{array}{l}\text { Short-intermediate }(n=28) \\
\quad \text { VOR band }\end{array}$ & 3.1 & 5.0 & 6.0 \\
$\mathrm{~kg} \cdot \mathrm{ha}^{-1}$ & 1235 & 1594 & 1783 \\
Tall-intermediate $(n=30)$ & 6.1 & 8.0 & 10.0 \\
$\quad$ VOR band & 1802 & 2161 & 2539 \\
$\mathrm{~kg} \cdot \mathrm{ha}^{-1}$ & 10.1 & 12.0 & $17+$ \\
Tall $(n=26)$ & 2558 & 2917 & 3930 \\
$\quad$ VOR band & & & \\
$\mathrm{kg} \cdot \mathrm{ha}^{-1}$ & &
\end{tabular}

${ }^{2}$ Number of transects

$\mathrm{b} \mathrm{kg} \cdot \mathrm{ha}^{-1}$ based on VOR band-weight equation

significant $(P=0.001)$. Herbage ranged from $387 \mathrm{~kg} \cdot \mathrm{ha}^{-1}$ to $3930 \mathrm{~kg} \cdot \mathrm{ha}^{-1}$ with a mean of $1742 \mathrm{~kg} \cdot \mathrm{ha}^{-1}$. Transect VOR ranged from 0.16 to 17 VOR bands $(\bar{x}=6)$.

Validation of the model (Fig. 2) during the 2nd year of sampling clearly showed that prediction of standing herbage was excellent when sampling was confined to areas where soils were derived from sedimentary material. Approximately $85 \%$ of the individual transects fell within the $90 \%$ prediction limits (Table 1). In the validation data, VOR bands ranged from an average of 1.60 to 8.75 and clipped standing herbage ranged from $789 \mathrm{~kg} \cdot \mathrm{ha}^{-1}$ to 3571 $\mathrm{kg} \cdot \mathrm{ha}^{-1}$. An “absolute-0" transect was never encountered in this vegetation type.

Cluster analyses (ISODATA) based on VORs resulted in 4 distinct minimum-variance VOR categories. These VOR categories are short (0.16-3.0 bands), short-intermediate (3.1-6.0 bands), tall-intermediate (6.1-10.0 bands) and tall (10.1-17+ bands; Table 2).

The estimated number of stations required per transect to achieve a precision of $20 \%$ of the mean with $80 \%$ confidence is 20 . Estimated number of transects required for detecting differences between and among the VOR resource groups is 3 . Based on the overall regression variance, we estimated that 4 transects would provide enough precision at $\alpha=$ 0.20 to detect differences of 2 VOR band widths (e.g., band 3 vs. band 5).

Vegetation at altitudes $>2814 \mathrm{~m}$ was generally short, ranging between 1.6 and 2.4 VOR bands at the $95 \%$ confidence interval. Herbage at high altitudes ranged from $763 \mathrm{~kg} \cdot \mathrm{ha}^{-1}$ to
$1109 \mathrm{~kg} \cdot \mathrm{ha}^{-1}$ (95\% confidence interval) with a mean of $936 \mathrm{~kg} \cdot \mathrm{ha}^{-1}$.

\section{Discussion}

To more accurately differentiate VORs for very short vegetation, we changed the Robel pole VOR band width of $2.54 \mathrm{~cm}$ (1 inch) used by Benkobi et al. (2000) to $1.27 \mathrm{~cm}$ (0.5 inch). These narrow VOR bands allowed more accurate measurement of vegetation within VORs under $2.54 \mathrm{~cm}$ (1 inch). Areas with such short vegetation are present on the Bighorn National Forest at elevations above $2814 \mathrm{~m}$ and in some key areas used for monitoring.

Studies by Vermeire and Gillen (2001) on tallgrass prairie and Vermeire et al. (2002) on shortgrass plains produced regressions with coefficients similar to ours but with different y-intercepts. Two studies (Benkobi et al. 2000, Vermeire et al. 2002) on mixed grass prairie likewise produced regressions with coefficients similar to each other (and different from ours) but with different y-intercepts. These studies suggest that a general Robel pole calibration encompassing a broad range of vegetation types may not be possible.

Validation of the developed model demonstrated that it behaved approximately as predicted, with $85 \%$ of transects falling within the $90 \%$ prediction limits. The model underestimated 2 sites outside the production limits (Table 1).

We used nonoverlapping confidence intervals to estimate the sample size required to detect differences among samples given the 
variance of the regression. To detect 2 VOR band differences in standing herbage (e.g., band 3 vs. band 5), we recommend a minimum of 4 transects. We also recommend that these methods be applied for monitoring key areas or other areas of special concern that are $\leq 269$ ha (640 acres; Benkobi et al. 2000). Most key areas (Holechek et al. 1989) for monitoring on the Bighorn National Forest range in area from approximately 12 to 269 ha with an average of 62 ha (data on file at Bighorn National Forest, Sheridan, WY). Detecting differences between adjacent VOR bands is not practical using the variance of the regression model. However, if the objective is to detect the difference between the mean of a set of Robel pole transects and a standard for standing herbage, a 1sided $t$ test is appropriate. In this case, the variance of the 4 transects would be used for the 1 -sided $t$ test analyses rather than the variance of the regression model, which is used in the nonoverlapping confidence intervals method. To characterize an entire allotment, we recommend sampling each section $(\leq 269$ ha $[640$ acres]) with 4 transects.

Using 20 stations with 4 readings per station is required to detect differences between and among VOR categories (Table 2). These numbers of stations and transects are also supported by research conducted on the prairie grasslands (Benkobi et al. 2000). Higher sampling densities are required to achieve reliability and precision with a $>80 \%$ confidence of being within $20 \%$ of the mean between categories.

In our study, we sampled a broad range of conditions to define general guidelines for resource management. Development of VOR band standards for management was based on standing herbage from this study and others, including Hurd (1961), Nesser (1986), and Trlica et al. (1980), all of which examined vegetation production on sedimentary soils on the Bighorn National Forest. Average standing herbage in this study ranged from $688 \mathrm{~kg}$. $\mathrm{ha}^{-1}$ to $3930 \mathrm{~kg} \cdot \mathrm{ha}^{-1}$. This study encompassed the variability of previous studies conducted on the Bighorn National Forest. Hurd (1961) reported that standing herbage ranged from $871 \mathrm{~kg} \cdot \mathrm{ha}^{-1}$ to $3711 \mathrm{~kg} \cdot \mathrm{ha}^{-1}$ in the same area. Nesser (1986) reported a low of $1426 \mathrm{~kg} \cdot \mathrm{ha}^{-1}$ and a high of $2970 \mathrm{~kg} \cdot \mathrm{ha}^{-1}$. Trlica et al. (1980) reported a low of $1054 \mathrm{~kg}$. $\mathrm{ha}^{-1}$ and a high of $3789 \mathrm{~kg} \cdot \mathrm{ha}^{-1}$. The overall means reported in the 3 studies were 1742 , 1964 , and $2066 \mathrm{~kg} \cdot \mathrm{ha}^{-1}$, respectively.

Based on the excellent agreement among the 3 studies, our resource categories (Table 2) of Robel pole readings developed through cluster analysis are intended to provide management and monitoring guidelines at a broader scale. Therefore, our guidelines are useful throughout the sedimentary soils on the Bighorn National Forest. The categories we developed through cluster analysis may be used as broad grazing management guidelines. The tall, tall-intermediate, short-intermediate, and short groups correspond to none, light, moderate, and heavy grazing categories.

For transitioning from monitoring forage utilization to monitoring residual vegetation, limits can be based on standing herbage and then converted to VOR band numbers. We used $2917 \mathrm{~kg} \cdot \mathrm{ha}^{-1}$, the mean of the "tall" transect group, as representative of mean annual vegetative production. For example, grazing a pasture to a level of 6.0 VOR bands (7.6 $\mathrm{cm}$ or 3.0 inches) corresponds to $40 \%$ use of standing herbage. Leaving herbage at an average of 3 VOR bands ( $3.8 \mathrm{~cm}$ or 1.5 inches) for the 4 transects corresponds to $60 \%$ use.

When grazing reduces the mean of 4 Robel transects to a predetermined band level, livestock should be removed. Under this scheme, stocking rates could be variable for a pasture or area. For example, many livestock can be on a pasture for a short duration or a few for a long duration. Managers can use VOR-based monitoring to prevent residual vegetation from being reduced to a point where resource values are being damaged (e.g., decreased herbage production, increased water runoff, erosion, changes in community structure, and entry of invasive species). These values can be measured concomitantly with the Robel pole, and guidelines can be adjusted appropriately (Bement 1969, Heady and Child 1994).

Associating GPS points with transects and dispersing transects over the entire management area allowed us to search for areas where the potential for vegetative production was low and, consequently, where special management was appropriate. We identified a class of such areas at elevations above $2814 \mathrm{~m}$.

Four species-Idaho fescue (Festuca idahoensis), upland sedge (Carex obtusata), pale agoseris (Agoseris glauca), and silky lupine (Lupinus sericeus)—are characteristic of the 
Idaho fescue community in the area reported by Hurd (1961). Livestock preferred grasses and sedges over forbs (Hurd and Pond 1958). The Robel pole as currently developed does not address management issues related to differential grazing, such as the proportion of standing herbage that is actually forage, forage quality, forage palatability, and long-term changes in the vegetative community.

\section{MANAGEMENT IMPLICATIONS}

The relationship of visual obstruction to herbage weight was developed as a tool for monitoring montane grasslands by structure categories and herbage weight from peak standing herbage through the end of the growing season. The method is accurate, precise, easily learned, and much faster than clipping, drying, and weighing vegetation (Benkobi et al. 2000, Vermeire and Gillen 2001). Monitoring can be based on the pole VOR bands or on standing herbage $\left(\mathrm{kg} \cdot \mathrm{ha}^{-1}\right)$ within the 4 structural categories, from short to tall, with a high degree of accuracy. We recommend that managers use 4 transects to meet multiple resource objectives. Additional research may be necessary to develop the appropriate information for managing areas above $2814 \mathrm{~m}$ in elevation. The vegetation at and above this elevation is considered alpine vegetation. Plant species composition is much different and Idaho fescue plants are of shorter stature and lower weight in alpine areas.

This tool provides a simple and precise method of monitoring rangelands on sedimentary soils in the Bighorn National Forest. The modified pole may be used to provide information for grazing and wildlife management, and most importantly information for resource guidelines to maintain the structure of a plant community for plant diversity and herbage production. It gives resource managers a fast, easy-to-use, highly accurate, and cost-effective method for monitoring and making resource management decisions.

\section{ACKNOWLEDGMENTS}

We thank the Bighorn National Forest for partial funding of this study. Thanks are extended to staff of the Bighorn National Forest: Ron Stellingwerf, Craig Yancey, David Beard, David Morris, Beth Bischoff, Josh Voorhis, and Zachary Palm. Rudy King, station biome- trician, provided statistical advice. Jody Javersak, James Margadant, Martin Tarby, Ben Hauser, and Levi Arnio collected data in the field. Thanks are extended to Rick and Roberta Young for their hospitality at the Bear Lodge.

\section{Literature Cited}

Ball, G.H., AND D.J. HaLL. 1967. A clustering technique for summarizing multivariate data. Behavioral Science 12:153-155.

BeEtLe, A.A. 1956. Range survey in Wyoming’s Big Horn Mountains. Wyoming Agricultural Experiment Station Bulletin 341, Laramie, WY. 40 pp.

BEMENT, R.E. 1969. A stocking-rate guide for beef production on blue-grama range. Journal of Range Management 22:83-86.

Benkobi, L., D.W. Uresk, G. Schenbeck, and R.M. KING. 2000. Protocol for monitoring standing crop in grasslands using visual obstruction. Journal of Range Management 53:627-633.

Del Morel, R. 1975. Vegetation clustering by means of ISODATA: revision by multiple discriminant analysis. Vegetatio 29:179-190.

Girard, M., D.L. Wheeler, and S.B. Mills. 1997. Classification of riparian communities on the Bighorn National Forest, R2-RR-97-02. USDA Forest Service, Region 2, Lakewood, CO. 308 pp.

Graybill, F.A. 1976. Theory and application of the linear model. Duxbury Press, North Scituate, MA. 704 pp.

HEADY, H.F., AND R.D. CHILD 1994. Rangeland ecology and management. Westview Press, Boulder, CO. $519 \mathrm{pp}$.

Hettmansperger, T.P., and J.W. McKean. 1998. Robust nonparametric statistical methods. John Wiley \& Sons, Inc., New York. 467 pp.

Holecher, J.L., R.D. Pieper, and C.H. Herbel. 1989. Range management principles and practices. Prentice Hall, Englewood Cliffs, NJ. 501 pp.

HuRD, R.M. 1961. Grassland vegetation in the Big Horn Mountains, Wyoming. Ecology 42:459-467.

Hurd, R.M., AND F.W. Pond. 1958. Relative preference and productivity of species on summer cattle ranges, Big Horn Mountains, Wyoming. Journal of Range Management 11:109-114.

Nesser, J.A. 1986. Soil survey of Bighorn National Forest, Wyoming. Parts of Bighorn, Sheridan, and Washakie Counties. USDA Forest Service-Soil Conservation Service in cooperation with Wyoming Agricultural Experiment Station, Federal Office Building, Room 3120, 100 East B Street, Casper, WY 82601-1911. $99 \mathrm{pp}$.

Neter, J., W. Wasserman, and W.H. Kutner. 1989. Applied linear regression models. 2nd edition. Irwin, Homewood, IL. 667 pp.

Robel, R.J., J.N. Briggs, A.D. Dayton, and L.C. HulBERT. 1970. Relationships between visual obstruction measurements and weight of grassland vegetation. Journal of Range Management 23:295-297.

SPSS. 2003. SPSS Base 12.0 for Windows user guide. SPSS, Inc., Chicago, IL. 703 pp.

Steel, R.G., AND J.H. Torrie. 1980. Principles and procedures of statistics. 2nd edition. McGraw-Hill, New York. 633 pp. 
Trlica, M.J., R. Jepson, and D. Hansen. 1980. An evaluation of the Wyoming bunchgrass scorecard as applied to rangelands in the Bighorn National Forest. Unpublished.

USDA NRCS. 1990. Technical guide, Section IIE, Foothills and mountains, eastern Wyoming. Available from: http://www.nrcs.usda.gov/technical/efotg/.

Vermeire, L.T., A.C. Gangull, And R.L. Gillen. 2002. A robust model for estimating standing crop across vegetation types. Journal of Range Management 55: 494-497.

Vermeire, L.T., and R.L. Gillen. 2001. Estimating herbage standing crop with visual obstruction in tall grass prairie. Journal of Range Management 54:5760.

Volesky, J.D., W.H. Schacht, and P.E. ReEce. 1999. Leaf area, visual obstruction, and standing crop relationships on Sandhills rangeland. Journal of Range Management 52:494-499.

[WRCC] Western Regional Climate Center. 2005. Historical climate information. Desert Research Institute, Reno, NV. Available from: http://www.wrcc .dri.edu/cgi-bin/cliain.pl?wy1220

Received 10 November 2005 Accepted 12 July 2007 